\title{
Expression of trypsin-like activity by the genera Corynebacterium and Actinomyces in canine periodontitis
}

\author{
KAZUKO TAKADA and MASATOMO HIRASAWA
}

Department of Microbiology, Nihon University School of Dentistry at Matsudo, Chiba 271-8587, Japan

\begin{abstract}
Trypsin-like activity (TLA), clinical parameters and TLA-postitive bacteria were examined in periodontitis and healthy sites in dogs. TLA was markedly higher in periodontitis than at healthy sites. There was good correlation between TLA positivity and severity of periodontal disease. The proportions of TLA-positive bacteria to total isolates in periodontitis and healthy sites were $21.1 \%$ and $2.1 \%$, respectively. Among TLA-positive bacteria in periodontitis sites, 4.4\% showed strong TLA activity, 35.3\% showed moderate and $60.3 \%$ showed weak activity. In the healthy sites, all the TLApositive bacteria showed weak activity. In all, $90 \%$ of the total number of TLA-positve bacteria were identified as belonging to the family Actinomycetaceae; $40 \%$ of bacteria belonging to the family Actinomycetaceae were identified as genus Corynebacterium with moderate trypsin-like activity and the remaining $60 \%$ were identified as genus Actinomyces with weak activity. Obligately anaerobic bacteria accounted for only $5.9 \%$ of the total population of TLA-positive bacteria; they were gram-negative coccobacilli, gram-positve rods and gram-positive cocci. These observations suggested that bacteria in the family Actinomycetaceae may play an important role in periodontitis and that measurement of TLA is a clinically reliable marker for the diagnosis of periodontitis in dogs.
\end{abstract}

\section{Introduction}

Periodontitis is an infectious disease caused primarily by micro-organisms that affect the supporting tissues of the teeth. Black-pigmented, anaerobic, gram-negative rods such as Porphyromonas spp. and Prevotella spp. have been implicated as key pathogenic and causative agents of periodontitis in both man and dogs [1-5]. Bacteria produce various kinds of enzymes, metabolic end-products and toxins that directly damage periodontal tissues, resulting in bone loss. Some of the periodontal bacteria such as Por. gingivalis, Bacteroides forsythus, Treponema denticola and some Capnocytophaga spp. possess a trypsin-like enzyme and are considered to be periodontopathic [6-10]. These bacteria hydrolyse the synthetic trypsin substrates $\mathrm{N}$ benzoyl-DL-arginine-2-naphthylamide (BANA) and N-carbobenzoxy-glycyl-glycyl-arginyl-3,5-dibromo-4hydroxyaniline (DBHA). BANA and DBHA have been used to develop rapid and simple methods for diagnosis

Received 4 Oct. 1999; accepted 19 Nov. 1999.

Corresponding author: Dr K. Takada (e-mail: ktakada@, mascat.nihon-u.ac.jp). and monitoring of periodontal therapy in human periodontitis $[6,7]$.

The aim of the present study was to determine whether there is a relationship between the presence of trypsinlike activity (TLA)-positive bacteria and periodontitis and to isolate and characterise TLA-positive bacteria in dogs.

\section{Materials and methods}

\section{Subjects and clinical examination}

Four female beagles, aged 3-7 years with periodontitis ranging from moderate to severe, and three periodontally healthy female beagles, aged 3-4 years, were studied. The dogs were housed in separate cages and fed a canine diet, with water available ad libitum. Dogs were generally healthy and had not received antibiotics before the study. Studies were performed in accordance with the ethical guidelines for animal experiments at the Animal Research Center of Nihon University School of Dentistry at Matsudo.

Eight periodontal pockets and six normal gingival 
crevices (two sites in each dog) were examined. The clinical parameters measured were: gingival crevicular fluid (GCF) - the volume of fluid in the pockets was determined by placing paper that absorbs GCF in the pocket for $5 \mathrm{~s}$, then the moistened area was measured immediately with a Periotron (Harco Medical, Tustin, CA, USA); pocket depth (PD) - measured to the nearest $\mathrm{mm}$ with a standard periodontal probe; probing depth - measured at the deepest site of the periodontal pocket on the buccal surface of the tooth; and bleeding of the gums on probing (BOP, 0.5-mm diameter probe), classified as negative or positive.

\section{Measurement of TLA}

TLA was measured by the SK-013 method [7], now commercially developed as the Periocheck periodontal diagnostic kit (Sunstar, Takatsuki, Japan). Briefly, three paper points were placed in the pocket for $30 \mathrm{~s}$, then placed into a small vial containing substrate (DBHA), chromogen and ascorbic oxidase solution, followed by agitation for $10 \mathrm{~s}$. The mixture was then incubated at $37^{\circ} \mathrm{C}$ for $15 \mathrm{~min}$. The OD was measured spectrophotometrically at $666 \mathrm{~nm}$. The enzymic activity was calculated from a standard curve and recorded as trypsin units (DBHA TU/ml).

The quantitative assay of TLA for cultivable bacteria was performed with BANA and N-benzoyl-L-arginine$p$-nitroanilide (BAPNA) as substrates as described previously $[8,11]$. Briefly, $100 \mu \mathrm{l}$ of BANA $(1.0 \mathrm{mM})$ or BAPNA $(1.8 \mathrm{~mm})$ were added to $100 \mu \mathrm{l}$ of the various bacterial cell suspensions in the wells of a plastic microtitration plate (Iwaki Sciteck DIV, Chiba, Japan). The mixtures were incubated at $37^{\circ} \mathrm{C}$ for $4 \mathrm{~h}$, and the colour was developed by additions of $10 \mu \mathrm{l}$ each of SDS $10 \% \mathrm{w} / \mathrm{v}$ in $2 \mathrm{M}$ Tris $/ \mathrm{HCl}, \mathrm{pH} 8.0$, and Fast Blue BB salt $0.35 \% \mathrm{w} / \mathrm{v}$ in 2-methoxyethanol solution only for BANA. The absorbances at $492 \mathrm{~nm}$ for BANA and at $415 \mathrm{~nm}$ for BAPNA were measured with a microplate reader (Corona Electric, Ibaragi, Japan). TLA-negative bacteria showed absorbance of 0 at $492 \mathrm{~nm}$ or $415 \mathrm{~nm}$ when the cell suspension with an $\mathrm{OD}_{540}$ value of 1.0 was used. TLA was calculated in trypsin units (BANA or BAPNA TU/ml), with trypsin (Wako Pure Chemicals, Japan) as a standard. The qualitative TLA was performed by the API-ZYM system (bioMérieux, Marcy-l'Etoile, France) according to the manufacturer's instructions.

\section{Microbiological examination}

GCF was obtained by placing paper points in each site for $10 \mathrm{~s}$, which were then quickly transferred to $500 \mu \mathrm{l}$ of reduced transport fluid [12] and immediately placed in an anaerobic glove box (Forma Scientific anaerobic system model 1024). Each sample was sonicated, diluted and plated on Gifu Anaerobic Medium (Nissui, Tokyo, Japan) agar with rabbit blood $5 \% \mathrm{v} / \mathrm{v}$ and containing haemin $0.0005 \% \mathrm{w} / \mathrm{v}$ and menadione $0.0001 \% \mathrm{w} / \mathrm{v}$ for culture. The plates were incubated at $37^{\circ} \mathrm{C}$ for 5 days. The numbers of colonies were counted and total viable bacterial numbers were determined.

Approximately 40 well separated colonies were picked at random and subcultured on pairs of identical plates, and one of each pair was incubated anaerobically and the other aerobically. All isolates were characterised by Gram's stain and TLA assay. The identities of the isolates were determined with the commercial APICORYNE, API-ANAEROBE, API ZYM and API $50 \mathrm{CH}$ systems (bioMérieux) following the manufacturer's instructions. For TLA assay, the cells were harvested from plates, washed three times in Sorensen buffer [8] and resuspended in the same buffer to give an $\mathrm{OD}_{540}$ value of 1.0. Serial two-fold dilutions of the cell suspensions were prepared to determine the detection limits of the TLA assay. The bacterial cell numbers were also counted in an EKDS Chamber (Sugagaki Med, Tokyo, Japan).

\section{Statistical analysis}

The data were analysed statistically by calculating means and SDs. Differences between means of the periodontal and healthy sites were evaluated by Student's $t$ test (Excel version 5.0; Microsoft, WA, USA).

\section{Results}

The clinical parameters of the dogs with periodontitis and periodontally healthy sites are summarised in Table 1. Differences between periodontitis and healthy sites were significant for all clinical parameters.

Fig. 1 shows the relationships between the TLA and

Table 1. Clinical parameters of sampling sites in healthy dogs and dogs with periodontitis

\begin{tabular}{lccccc}
\hline Group & Number of dogs & $\begin{array}{c}\text { Number of sampling } \\
\text { sites }\end{array}$ & Pocket depth* $(\mathrm{mm})$ & GCF value* & $\begin{array}{c}\text { Frequency of bleeding } \\
\text { on probing }\end{array}$ \\
\hline Healthy & 3 & 6 & $2.16(1.04)^{\dagger}$ & $38.0(9.6)^{\dagger}$ & $0 / 6^{\dagger}$ \\
Periodontitis & 4 & 8 & $5.25(1.47)^{\dagger}$ & $116.8(25.3)^{\dagger}$ & $7 / 8^{\dagger}$ \\
\hline${ }^{*}$ Mean (SD). & & & & \\
${ }^{\dagger} \mathrm{p}<0.005$. & & & &
\end{tabular}




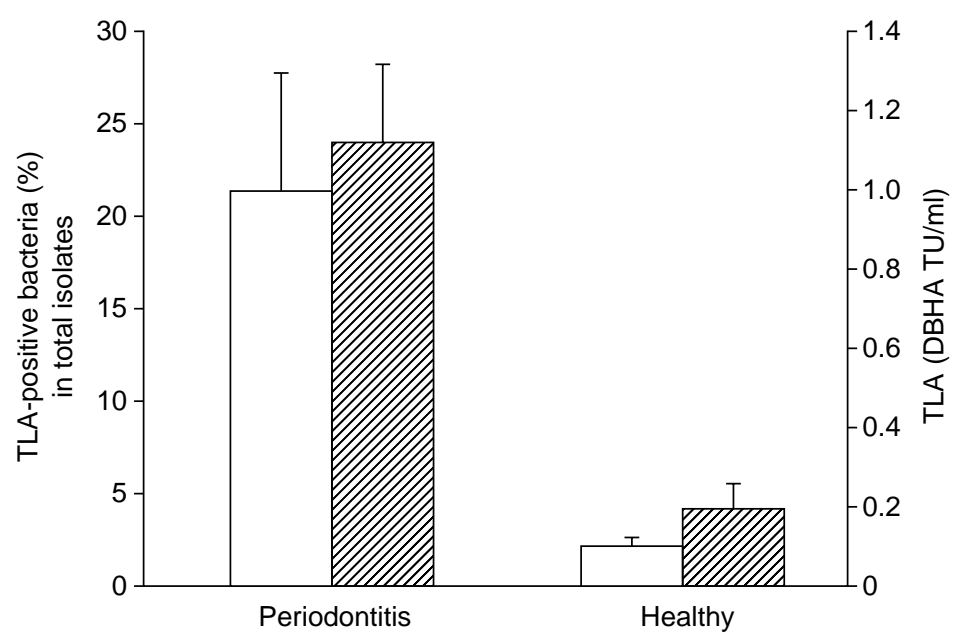

Fig. 1. Relationship between frequency of TLA-positive bacteria in total isolates and TLA seen with Periocheck kit

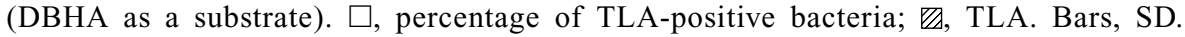

frequency of TLA-positive bacteria at periodontitis and healthy sites. The average recoveries of total cultivable bacteria were $1 \times 10^{8} \mathrm{cfu} / \mathrm{ml}$ at periodontitis sites and $1 \times 10^{7} \mathrm{cfu} / \mathrm{ml}$ at healthy sites, respectively. TLApositive bacteria were found to represent $21.1 \%$ of the total isolates at periodontitis sites. In contrast, healthy sites showed only $10 \%$ of this number of TLA-positive bacteria. TLA values measured by a Periocheck kit (ability to hydrolyse DBHA) were 1.16 and 0.21 DBHA $\mathrm{TU} / \mathrm{ml}$ in periodontitis and healthy sites, respectively.

Fig. 2 shows the standard curves of TLA prepared with BANA (Fig. 2a) and BAPNA (Fig. 2b) as substrates. Quantitative linear curves were obtained with $0.02-$ 0.20 BANA TU/ml and $0.01-0.08$ BAPNA TU $/ \mathrm{ml}$ by the microplate assay. Both substrates were used for all cultivable bacteria isolated.

TLA-positive bacteria from both periodontitis and healthy sites were isolated and TLA was measured with BANA as the substrate (Table 2). Weak, moderate and strong TLA corresponded to API-ZYM values of $1-2,3-4$ and $>5$, respectively. Of a total of 238 isolates from healthy sites, five showed weak activity and no moderate or strongly positive isolates were found. However, among 315 isolates from periodontitis sites, 41 showed weak TLA, 24 showed moderate TLA and three showed strong TLA.

Further characteristics of TLA-positive bacteria are summarised in Table 3. Approximately $90 \%$ of all TLA-positive isolates were filamentous, gram-positive and facultatively anaerobic bacteria. They were identified as belonging to the family Actinomycetaceae. Among these Actinomycetaceae isolates in periodontitis sites, $40 \%$ belonged to the genus Corynebacterium and showed moderate TLA of 1.75 SD 0.23 BANA TU/ml, and $60 \%$ belonged to the genus Actinomyces and showed weak TLA of 0.65 SD 0.29
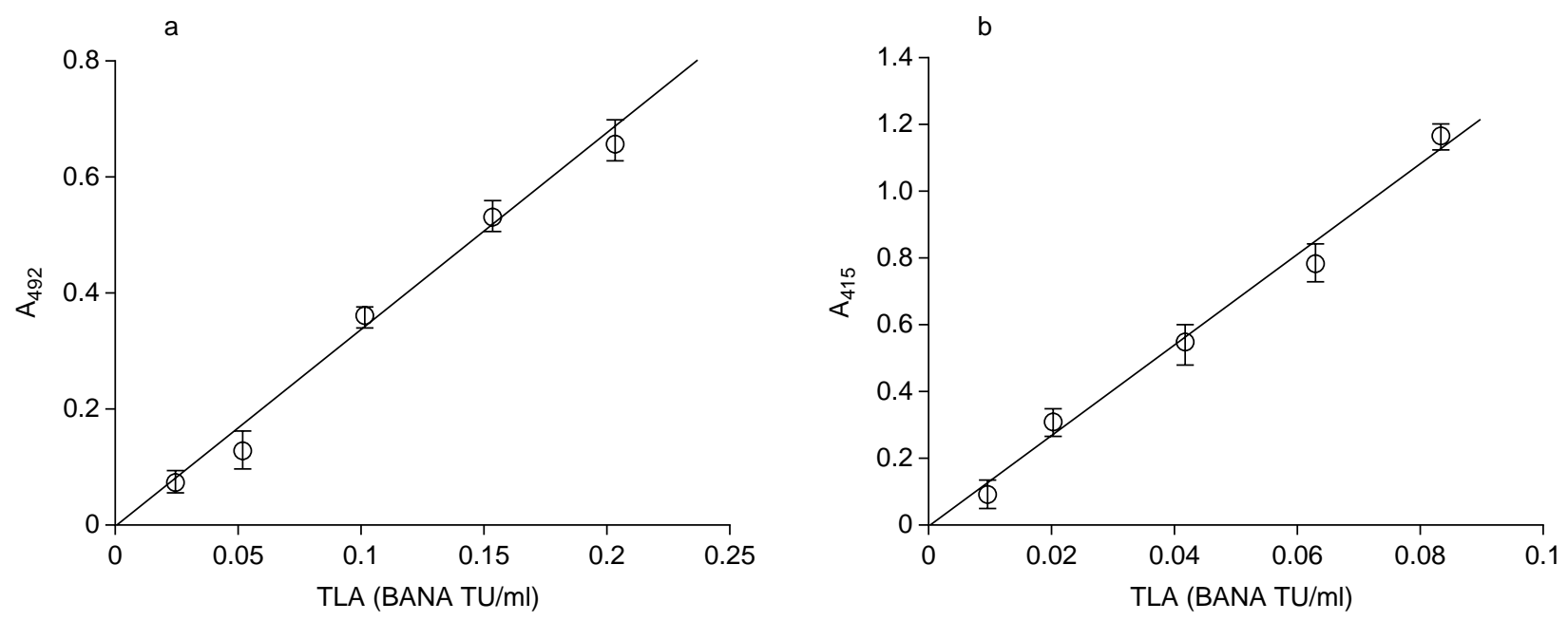

Fig. 2. Standard curve for TLA obtained with (a) BANA, (b) BAPNA, as a substrate. The data are plotted as the mean (O) and SD. 
Table 2. Distribution of TLA-positive bacteria

\begin{tabular}{lcccc}
\hline & & \multicolumn{2}{c}{ Number of isolates with TLA (BANA TU/ml) } \\
\cline { 3 - 5 } Group & Total & $(0.2 \sim 1.0)$ & $\begin{array}{c}\text { Moderate } \\
(1.0 \sim 2.0)\end{array}$ & Strong \\
& 238 & 5 & 0 & 0 \\
\hline Healthy & 315 & 41 & 24 & 3 \\
Periodontitis & & &
\end{tabular}

Table 3. Characterisation of TLA-positive bacteria from canine periodontal sites

\begin{tabular}{|c|c|c|c|c|c|c|}
\hline \multirow[b]{2}{*}{ Family/genus } & \multirow[b]{2}{*}{ Shape } & \multirow{2}{*}{$\begin{array}{l}\text { Gram's } \\
\text { stain }\end{array}$} & \multirow{2}{*}{$\begin{array}{l}\text { Anaerobiosis } \\
\text { requirements }\end{array}$} & \multicolumn{2}{|c|}{ Mean (SD) TLA (U/ml) } & \multirow{2}{*}{$\begin{array}{l}\text { Percentage of TLA- } \\
\text { positive bacteria }\end{array}$} \\
\hline & & & & BANA & BAPNA & \\
\hline Actinomycetaceae & Filamentous & $\ldots$ & & & & \\
\hline Actinomyces & Some branching & + & Facultative & $0.65(0.29)$ & $0.13(0.06)$ & $54.4(100)^{*}$ \\
\hline Corynebacterium & Whip-like & + & Facultative & $1.75(0.23)$ & $0.18(0.05)$ & 35.3 \\
\hline ND & Rods & + & Obligate & 1.01 & 0.31 & 2.9 \\
\hline ND & Coccobacillus & - & Facultative & 9.91 & 2.28 & 2.9 \\
\hline ND & $\begin{array}{l}\text { Coccobacillus } \\
\text { Coccus }\end{array}$ & - & Obligate & 9.59 & 2.60 & 1.5 \\
\hline ND & Pair & - & Facultative & 1.19 & 0.54 & 1.5 \\
\hline ND & Chain & + & Obligate & 0.99 & 0.48 & 1.5 \\
\hline
\end{tabular}

$\mathrm{ND}$, not determined.

* Number in parentheses indicates isolates from healthy site.

BANA TU/ml. At the healthy sites, all TLA-positive bacteria were from the genus Actinomyces and had weak activity. These bacteria belonging to the family Actinomycetaceae also showed weak ability to hydrolyse BAPNA $(<0.2$ BAPNA TU/ml). Obligately anaerobic bacteria accounted for $5.9 \%$ of all TLA-positive bacteria, and one showed strong TLA - 9.59 BANA $\mathrm{TU} / \mathrm{ml}$ and 2.60 BAPNA TU/ml. The others had weak TLA. Obligately anaerobic bacteria were found only in periodontitis sites. The bacteria with highest hydrolytic activity for BANA were a gram-negative, facultatively anaerobic coccobacillus with TLA values of 9.91 BANA $\mathrm{TU} / \mathrm{ml}$ and 2.28 BAPNA $\mathrm{TU} / \mathrm{ml}$; there was only one isolate and it was from a periodontitis site. A gram-negative, facultative anaerobic diplococcus with weak TLA was also found in periodontitis sites.

\section{Discussion}

Periodontal disease is the most common oral disease in dogs $[13,14]$. There have been many investigations concerning periodontitis in dogs and man $[1,8,14]$. The accumulation of plaque and calculus on tooth surfaces, particularly at the gingival margin in dogs, causes an increase in the number of micro-organisms within the gingival pocket and progression and development to periodontitis. Diagnostic tests for human periodontal infections have been developed based on the hydrolysis of trypsin-like enzyme substrates BANA and DBHA by micro-organisms in subgingival plaque and crevicular fluid $[7,15,16]$. However, there are very few BANA-positive species among the cultivable plaque flora [17]. The three species, Por. gingivalis, B. forsythus and T. denticola, are always positive for BANA hydrolysis $[6,7,9]$. Other BANA hydrolytic species in man were reported to include some Capnocytophaga spp. [8] and Actinomycetaceae [18].

The present investigation applied a diagnostic test to periodontal disease in dogs. This study extended earlier findings by comparison of the TLA test for dogs with a commercially available Periocheck kit. The enzymic activity was higher in disease sites than in healthy sites (Fig. 1). The recoveries of total cultivable and TLApositive bacteria at periodontal sites were both 10 -fold higher than those at healthy sites, i.e., the numbers of TLA-positive bacteria at periodontal sites were 100fold greater than those at healthy site. The magnitude of DBHA-hydrolysing activity was correlated with proportions of TLA-positive bacteria, and with the periodontal status of the subjects (Tables 1 and 2). Isolation and characterisation of TLA-positive bacteria yielded several different bacteria (Table 3). Although Por. gingivalis from man has strong TLA, Porphyromonas spp. isolated from dogs do not produce trypsinlike enzymes [2, 4, 19]. Some studies [3, 20] have reported that black-pigmented, anaerobic gram-negative rods from periodontitis in dogs have TLA. However, genotypic characterisation is needed to identify the genus and species of these isolates. Furthermore, there have been few reports concerning B. forsythus, spirochaetes, Capnocytophaga spp. and Actinomycetaceae from dogs. Human isolates of these bacteria have trypsin-like enzymes. Some of the weakly TLA-positive bacteria found in the present study, which were gram-negative coccobacilli (Table 3), might have been similar to the organisms described by Karjalainen et al. [3]. However, these strains showed no pigmentation. In 
the present study, $90 \%$ of the TLA-positive bacteria were members of the Actinomycetaceae (Table 3). These results indicate that members of the family Actinomycetaceae are major contributors to TLA in the gingival pocket in dogs.

The progression and development of periodontitis in dogs might be different from those in man. Plaque and calculus formation in dogs became more severe than that in man. C. matruchotii, which has the strongest calculus-forming ability, is very important not only in supragingival plaque but also in subgingival plaque and crevicular fluid $[21,22]$. Colonies of whip-like bacteria with moderate TLA (40\% of all Actinomycetaceae) were rough, tough and adherent to the medium, and were identified as belonging to the genus Corynebacterium. They were similar in shape to C. matruchotii (data not shown). The other $60 \%$ of the Actinomycetaceae bacteria were identified as belonging to the genus Actinomyces. The determination of the species of these bacteria must await genetic analysis. It is of interest that Actinomycetaceae from man, $R$. dentocariosa and $C$. matruchotii, produce trypsin-like enzyme [17] and $C$. matruchotii is stimulated to grow under anaerobic conditions by haemin [22]. In dogs, filamentous bacteria such as Actinomycetaceae might play the same role as Por. gingivalis in human periodontitis.

The use of chromogenic substrates for rapid detection of bacterial enzymic activities is a useful method for diagnosing and monitoring different periodontal conditions in dogs. The present findings can be summarised as follows: BANA hydrolysis was directly related to the number of periodontopathic bacteria in crevicular fluid; TLA positivity is a risk indicator for dogs associated with colonisation by the TLA-positive bacteria, increased probing depth and active periodontitis; and bacteria of the genera Corynebacterium and Actinomyces contribute to TLA.

\section{References}

1. Hennet PR, Harvey CE. Anaerobes in periodontal disease in the dog: a review. J Vet Dent 1991; 8: 9-11.

2. Hirasawa M, Takada K. Porphyromonas gingivicanis sp. nov. and Porphyromonas crevioricanis sp. nov., isolated from beagles. Int J Syst Bacteriol 1994; 44: 637-640.

3. Karjalainen J, Kanervo A, Väisänen M-L, Forsblon B, Sarkiala E, Jousimies-Somer H. Porphyromonas-like gram-negative rods in naturally occurring periodontitis in dogs. FEMS Immunol Med Microbiol 1993; 6: 207-212.
4. Love DN, Karjalainen J, Kanervo B et al. Porphyromonas canoris sp. nov., an asaccharolytic, black-pigmented species from the gingival sulcus of dogs. Int J Syst Bacteriol 1994; 44: 204-208.

5. Slots J. Subgingival microflora and periodontal disease. J Clin Periodontol 1979; 6: 351-382.

6. Bretz WA, Lopatin DE, Loesche WJ. Benzoyl-arginine naphthylamide (BANA) hydrolysis by Treponema denticola and/or Bacteroides gingivalis in periodontal plaques. Oral Microbiol Immunol 1990; 5: 275-279.

7. Ishihara $\mathrm{K}$, Naito $\mathrm{Y}$, Kato $\mathrm{T}$ et al. A sensitive enzymatic method (SK-013) for detection and quantification of specific periodontopathogens. J Periodont Res 1992; 27: 81-85.

8. Loesche WJ, Syed SA, Stoll J. Trypsin-like activity in subgingival plaque. A diagnostic marker for spirochetes and periodontal disease? J Periodontol 1987; 58: 266-273.

9. Loesche WJ, Bretz WA, Lopatin D et al. Multi-center clinical evaluation of a chairside method for detecting certain periodontopathic bacteria in periodontal disease. $J$ Periodontol 1990; 61: 189-196.

10. Takada K, Hirasawa M. Isolation and characterization of nonpigmented rough colony of Porphyromonas gingivalis from periodontitis. Anaerobe 1998; 4: 233-240.

11. Bretz WA, Loesche WJ. Characteristics of trypsin-like activity in subgingival plaque samples. J Dent Res 1987; 66: 16681672.

12. Syed SA, Loesche WJ. Survival of human dental plaque flora in various transport media. Appl Microbiol 1972; 24: 638-644.

13. Penman S, Harvey CE. Periodontal disease. In: Harvey CE, Simon Orr $\mathrm{H}$ (eds) Manual of small animal dentistry. Cheltenham, British Small Animal Veterinary Association. 1990: $37-48$.

14. Hayashi K, Takada K, Hirasawa M. Clinical and microbiological effects of controlled-release local delivery of minocycline on periodontitis in dogs. Am J Vet Res 1998; 59: 464467.

15. Gusberti FA, Syed SA, Hofmann T, Lang NP. Diagnostic methods for the assessment of potential periodontal disease activity: enzymatic activities of bacterial plaque and their relationship to clinical parameters. In: Lehner T, Cimasoni G (eds) The borderland between caries and periodontal disease III. Orlando, FL, Grune and Stratton. 1986: 165-174.

16. Syed SA, Gusberti FA, Loesche WJ, Lang NP. Diagnostic potential of chromogenic substrates for rapid detection of bacterial enzymatic activity in health and disease associated periodontal plaques. J Periodont Res 1984; 19: 618-621.

17. Loesche WJ, Bretz WA, Kerschensteiner D et al. Development of a diagnostic test for anaerobic periodontal infections based on plaque hydrolysis of benzoyl-DL-Arginine-Naphthylamide. $J$ Clin Microbiol 1990; 28: 1551-1559.

18. Kilian M. Rapid identification of Actinomycetaceae and related bacteria. J Clin Microbiol 1978; 8: 127-133.

19. Collins MD, Love DN, Karjalainen J et al. Phylogenetic analysis of members of the genus Porphyromonas and description of Porphyromonas cangingivalis sp. nov and Porphyromonas cansulci sp. nov. Int J Syst Bacteriol 1994; 44: $674-679$.

20. Fournier D, Mouton C. Phenotypic characterization of human and animal biotypes within the species Porphyromonas gingivalis. Res Microbiol 1993; 144: 435-444.

21. ten Cate JM (ed). Recent advances in the study of dental calculus. Oxford, IRL Press. 1989: 1-267.

22. Jones D, Collins MD. Irregular, nonsporing Gram-positive rods. In: Sneath PHA, Mair NS, Sharpe ME, Holt JG (eds) Bergey's manual of systematic bacteriology, vol 2. Baltimore, MD, Williams \& Wilkins. 1986: 1261-1434. 